\title{
Application of Gurindam 12 Local Wisdom Values in Malay Community Life in Tanjung Pinang City, Riau Islands
}

\author{
$1^{\text {st }} \mathrm{Ab}$. Marisyah \\ Student of Dep. of Historical Education, \\ Faculty of Social Studies, \\ Universitas Negeri Padang, \\ Padang, Indonesia \\ abemarissa01@gmail.com
}

\author{
$2^{\text {nd }}$ Siti Fatimah* \\ Lecturer of Dep. of Historical Education, \\ Faculty of Social Studies, \\ Universitas Negeri Padang, \\ Padang, Indonesia \\ sitifatimah@fis.unp.ac.id
}

\begin{abstract}
The purpose of this research is in the current era of globalization where we must be able to act locally by utilizing the knowledge of ancestors inherited, and must also be able to think globally with a future orientation. In this case the application of the values contained in the contents of Gurindam Dua Belas must continue to be preserved as character learning based on local wisdom. The research method used descriptive qualitative method. This qualitative research uses a case study approach, this research describes how the application of Gurindam 12 Local Wisdom Values in the life of the Malay Community in Tanjung Pinang City, Riau Islands and can find out what are the challenges in the application of Gurindam Local Wisdom Values
\end{abstract}

\section{INTRODUCTION}

Indonesia is one of the largest archipelagic countries in the world. Indonesia also has cultural diversity due to the diversity of its territory. As an example, people who live on the coast will have a different culture from those who live in the mountains. In each region, of course, also has a different local wisdom depending on the natural conditions. local community culture to regulate the structure of community life or said Local wisdom is a form of genuine knowledge in the community that comes from noble values that local wisdom is a
12 in the life of the Malay Community in the City of Tanjung Pinang, Riau Islands. The results showed that: 1)through the role of education that continues to promote the values of local wisdom that aims to avoid social conflicts, disagreements, criminalization, and disputes that result in casualties and losses; 2) raising the values of local wisdom such as Gurindan 12 as a source of innovation through local community-based cultural education; 3) Gurindan 12 as a form of appeal and advice for all community groups; 4) challenges that can be seen in the application of Gurindam Local Wisdom Values 12.

Keywords-Local Wisdom, Gurindam 12, Malay Community Life

form of cultural heritage that is in people's lives [1]. One of the local wisdoms of the Baduy who live in mountainous areas regarding the view of the universe [2]. Baduy people really maintain balance and harmony with nature. Therefore, the Baduy people really maintain the teachings about protecting nature and preserving it. Similar to the Maritime Community which has a local character like [3], local wisdom is characterized by a Tiku community with a strong and tidy collective (social-economic) order of life, patterns of utilization of marine resources that reflect inter subjective relations human environment. Conditions of socio- 
economic well-being of the population are evenly distributed. Maintaining the condition of environmental sustainability and the balance of marine resources.

Literature is a collection of essays (written works of imagination/imaginary) whose language (words) is beautiful and has a message that is good for life. The words are beautifully meaningful, containing assonance (equality of vocal sounds), alliteration (equality of consonant sounds), rhythm, poetry, expression, style/ language style [4]. An important element in literary works is the value of education [5]. Many literary works that feature stories or stories that have a high moral educational value. Such literary works are very potential to be used as a means of teaching character and example for its readers. The value of moral education shows the rules of behavior and customs of a person from a group that includes behavior, manners that uphold morality and moral values. The moral values contained in literary works aim to educate humans to recognize ethical values.

Value is something good that is always desired, aspired and considered important by all human beings as members of society, because that something is said to have value if it is useful and valuable value of truth, aesthetic value, both moral, religious and religious values [6]. Values are quality provisions that are meaningful to the lives of individuals, communities, nations, and countries. The presence of values in human life can cause action and reaction, so humans will accept or reject their presence. In the value contained 18 characters that can form morality, namely: 1)religious; 2) honestly; 3) tolerance; 4) discipline; 5) hard work; 6) creative; 7) autonomous; 8) democratic; 9) curiosity; 10) nationalism; 11) love the motherland; 12) rewarding achievements; 13) communicative; 14) peace-loving; 15) likes to read; 16) care for the environment; 17) social care; 18) responsible. Of the 18 characters contained in the values are also related to local wisdom.
Local wisdom is the ideas or ideas of the local people that have wisdom and wisdom values that are still maintained by the community through generations. Local wisdom is the identity or cultural personality of a nation that causes the nation to be able to absorb, even cultivate a culture that comes from outside/ other nations become their own character and abilities [7]. These identities and personalities certainly adjust to the viewpoints of the surrounding community so that values do not occur. Local wisdom is a means of cultivating culture and defending yourself from unfamiliar foreign cultures. Local wisdom is a view of life and science as well as a variety of life strategies in the form of activities carried out by local communities in answering various problems in meeting their needs. In a foreign language, it is often conceptualized as local wisdom, local wisdom or local genious local intelligence. Various strategies carried out by the local community to maintain its culture. Local wisdom according to [8] is a binding cement in the form of culture that already exists so that it is based on existence. Local wisdom can be defined as a culture created by local actors through an iterative process, through internalization and interpretation of religious and cultural teachings that are socialized in the form of norms and used as guidelines in people's daily lives.

[9] states that forms of local wisdom are a diversity of harmony in the form of social practices that are based on the wisdom of culture. Forms of local wisdom in society can be in the form of culture (values, norms, ethics, beliefs, customs, customary law, and special rules). Noble values related to local wisdom include love for God, the nature of the semester and its contents, responsibility, discipline, and independence, honesty, respect and courtesy, love and care, confidence, creativity, hard work, and never give up, justice and leadership, kind and humble, tolerance, peace, and unity. nature of local wisdom literary works is clearly a language, both oral and written Ratna [8]. In society, local wisdom can be found in folklore, 
chanting, proverbs, sasanti, advice, motto, and ancient books that are inherent in everyday behavior. This local wisdom will manifest into traditional culture, local wisdom will be reflected in the values prevailing in certain community groups.

Local wisdom has a close relationship with culture where according to the science of anthropology, "culture" is the whole system of ideas of actions and results of human work in the context of community life that belongs to human beings by learning. Each universal culture is certainly also incarnated in the three forms of culture that is in the form of cultural systems, social systems and physical cultural elements. It is said that there are seven cultural elements that can be found in all nations, the seven elements of culture are: 1) language; 2) knowledge system; 3) social organization system; 4) life equipment and technology system; 5) life livelihood system; 6) religious system; 7) art [10].

Tanjung Pinang is a city located in one of the areas in the Riau Islands. This city is a Malay region that has a lot of local wisdom, one of which is in the field of language, namely the existence of Gurindam 12. Gurindam 12 is a poetic form consisting of four lines. In the first line dank e two in this case write himabuan to the general public with values that are based on religion and education. Whereas in the second and third row is what happens to someone if only the advice is violated. In the contents of Gurindam 12 there are many moral messages in the form of appeals and advice that we get. Gurindan Dua Belas, which became an icon for the Tanjung Pinang ethnic Malay community, provides an understanding of real examples in the application of globalization. That is where we must be able to act locally by utilizing the knowledge of ancestors inherited, and must also be able to think globally with a future orientation. In this case the application of the values contained in the contents of Gurindam Dua Belas must continue to be preserved as character learning based on local wisdom.

\section{METHOD}

In accordance with the focus and problem of the research above, which is the Application of Gurindam 12 Local Wisdom Values in the life of the Malay Community in Tanjung Pinang, Riau Islands, this research is a descriptive study. Descriptive method is a method in examining the status of a group of people, an object, a set of conditions, a system of thought or a class of events in the present. The purpose of this descriptive study is to make a systematic, factual and accurate description, description, or painting of the facts, properties and relationships between the phenomena investigated [11].

The qualitative research uses a case study approach to describe the object under study in case study research only imaged itself in depth/detail/complete to obtain a complete picture of the object [12] in the sense that the data collected in the study are studied as a whole, integrated whole. That's why Case Study research is exploratory. The very special nature of the object of study becomes the main consideration of researchers to elaborate it by exploring deeply.

This study describes in depth and in detail how the application of Gurindam 12 Local Wisdom Values in the life of the Malay Community in Tanjung Pinang City, Riau Islands and can find out what are the challenges in the application of Gurindam 12 Local Wisdom Values in the life of the People of Gurindam 12 Malay in the City of Tanjung Pinang, Riau Islands. To obtain complete data, researchers are directly involved in the process of Interview, Observation, making Field Notes related to the problem being examined, so that research objectives can be achieved.

\section{RESULTS AND DISCUSSION}

Based on the results in the field after conducting research, some of the results found include: the contents of Gurindam 12 are: 
The first chapter Gurindam:

Whoever has no religion,

No name can ever be removed.

Who knows the four,

Then he is a person who ma'rifat

Whoever knows God,

Tell and stand there is no blame.

Anyone who knows themselves,

Then already know the God of Bahri.

Who knows the world,

You know it's a trusted product.

Who knows the afterlife,

He knows the world is bad.

Gurindam second article:

Whoever knows that,

He knew the meaning of fear.

Whoever leaves prayer,

Like a pillarless house.

Whoever leaves fasting,

It doesn't get two terms.

Whoever leaves the alms,

No treasure will be a blessing.

Whoever leaves the pilgrimage,

He did not complete the promise.

Gurindam third article:

If maintained by the eye,

Few ideals.

If the ears are preserved,

Evil khabar has no side.

If maintained the tongue,

Undoubtedly can be from him.

You earnestly keep your hands,

Instead of everything heavy and light.

If the stomach is too full,

Come out filial that is not obscene.

The middle member should remember,

That's where a lot of people lost their spirits

Let your feet be preserved.

Instead of running that brings loss.
The fourth chapter Gurindam:

The heart is a kingdom in the body,

Even if all the members are wrong,

When spiteful has landed,

Come from there a few arrows.

Curse and praise let think,

That's where many people slip.

Angry jobs don't be defended,

I will lose my head.

If you lie a bit,

It may be likened to a pekung mouth.

A sign of a very wretched person,

Disgrace himself he never thought.

Grabber don't be stopped by,

That's a very handsome robber.

Whoever is already big,

Do not be rude.

Whoever dirty words,

His mouth is like a ketor.

Where do you know yourself wrong,

If not other people who play.

The fifth chapter Gurindam:

If you want to hit a nation,

Look at the mind and the language,

If you want to get to know people

who are happy,

So looking after the futile.

If you want to get to know a noble

person,

Look at his behavior.

If you want to know someone who has knowledge,

Asking and learning is not bored.

If you want to get to know someone who is intelligent,

In the world take stock.

If you want to get to know a person who is good-tempered,

Look at it when mixed with crowded people.

Self-crime hide, Kindness let stand.

Don't open people's looser, 


\begin{tabular}{|c|c|}
\hline Your day will be a teacher, & Selfishness should be mistaken. \\
\hline \multicolumn{2}{|l|}{ You may know each enemy. } \\
\hline Giving you a wife, & Gurindam ninth article: \\
\hline Which may be surrendered? & Know the work is not good, but it is \\
\hline Your day will be comrades, & done, \\
\hline Choose everyone who is loyal. & Not human, that is shaitan. \\
\hline Your day will be 'servant, & The crime of an old woman, \\
\hline That there is a good little mind, & $\begin{array}{l}\text { That's the devil has penggawa. } \\
\text { To all the king's servants, }\end{array}$ \\
\hline The seventh chapter of Gurindam: & That's where the devil spoiled place \\
\hline If you have a lot of words, & Most people who are young, \\
\hline That's where the entrance lies. & That's where Satan's temptation is. \\
\hline If you overdo it, & A society of men and women, \\
\hline That is a sign of grief. & That's where shaitan has a feast. \\
\hline If we lack strategy, & As for thrifty parents, \\
\hline That is a sign of a job about to go astray. & Satan doesn't like to make friends \\
\hline If the child is not trained, & If young people are strong learners, \\
\hline If big the father is tired. & With devils become hostile. \\
\hline \multicolumn{2}{|l|}{ If you criticize a lot of people, } \\
\hline That is a sign that he is lacking. & Gurindam tenth article: \\
\hline If people who sleep a lot, & With fathers, don't be ungodly, \\
\hline It's useless for ages. & So that God is not angry. \\
\hline When you hear about it, & With mother be respectful, \\
\hline Accept it, be patient. & So the body can survive. \\
\hline When listening to complaints, & With children don't be negligent, \\
\hline Talking about it should be jealousy. & So you can go up to the middle of the \\
\hline When words are gentle, & hall. \\
\hline Hurry up and everyone follows. & With friends be fair, \\
\hline If the words are very rude, & So that his hands become chapel. \\
\hline \multicolumn{2}{|l|}{ Hurry up, everyone is upset. } \\
\hline If the work is very correct, & Gurindam eleventh article: \\
\hline \multirow[t]{2}{*}{ No one can honor. } & Be meritorious, \\
\hline & To compatriots. \\
\hline Gurindam eighth article: & Be a head, \\
\hline Whoever betrays himself, & Discard the blemish temperament. \\
\hline Especially to others. & Let hold of the mandate, \\
\hline To him he was persecuted, & Dispose of treason. \\
\hline Don't believe that person. & Angry will, \\
\hline A tongue that justifies itself, & Put it first. \\
\hline Instead of others getting the error. & Going through, \\
\hline Instead of praising yourself, be patient, & Do not pass. \\
\hline Let and people come preach. & Want to be crowded, \\
\hline People who like to show services, & Cheapen temperament. \\
\hline Half of shirk claimed power. & Gurindam twelfth chapter: \\
\hline The king agreed with the minister, & A sign of mercy on you. \\
\hline Like a garden with thorns. & Be respectful of smart people, \\
\hline True to the king, & Gauze and scan markings. \\
\hline
\end{tabular}




\begin{tabular}{ll}
\hline Signs become any work. & Remind himself dead, \\
The law 'is fair to the people, & That is the origin of worship. \\
The sign of the king is obtained ayat inayat. & The afterlife is too real, \\
Poor people who have knowledge, & To a heart that is not blind.
\end{tabular}

Not only the contents of gurindam 12 from the research results also found several things about, the role of education to preserve gurindam 12 which was published as a local content and what challenges occurred in people's lives at this time.

1. Through the role of education that continues to promote the values of local wisdom that aims to avoid social conflicts, disagreements, criminalization, and disputes that result in casualties and losses. Although the Malay tribe is an indigenous tribe but it still develops a culture of tolerance in accordance with the contents and messages of Gurindam 12.

2. Raising the values of local wisdom such as Gurindan 12 as a source of innovation through culture-based education of local communities, by empowering through the adaptation of local knowledge. The best way to be able to encourage the values of local wisdom contained in the City of Tanjungpinang is by including Gurindam 12 as a local content learning.

3. There are many things that can be taken as a form of appeal and advice for all community groups.

4. Challenges that can be seen in the application of Gurindam 12 Local Wisdom Values include: a). Globalization is increasing. b.) outside culture that is free in and out because the Riau archipelago is a border area.

The concept of local wisdom consists of two words, namely wisdom (wisdom) and local (local). Wisdom (wisdom) has the same meaning as wisdom, while local (local) has a local meaning. In general, local wisdom (local wisdom) can be understood as local ideas (local) that are wise, full of wisdom, good value, which are embedded and followed by members of the community [13]. Local wisdom is a form of original knowledge in society that comes from the noble value that local wisdom is a form of cultural heritage that exists in people's lives [14].

According to Taylor [15] culture is the overall complex of knowledge, beliefs, arts, morals, law, customs and all the abilities and other habits acquired by someone as a member of society. In this case, culture in society is also often referred to as civilization in English called civilization. In terms of humidity it is often studied in developed and complex urban societies. In addition, broad civilizations include knowledge in society, trust in society and others. Meanwhile, according to. Of the many thoughts of experts about what culture really is, in general the core understanding of culture: 1) that the cultures that exist between mankind are very diverse, 2) that culture is acquired and passed on socially through the learning process, 3)that culture is translated from the biological, sociological and psychological components of human existence, 4)that culture is structured; 5)that culture contains several aspects; 6)that culture is dynamic; 7)that values in culture are relative.

Gurindam simply has meaning as a poem. Gurindam 12 is a collection of poems created by Raja Ali Haji on Penyengat Island. As for he was a writer in the Riau Islands in his time and was recognized as one of the National Heroes. Regarding the reasons for Raja Ali Haji creating gurindam is as a dowry given to Engku Puteri Hamidah who lives on Penyengat Island. This dowry carved in marble as proof of his love.

From the theory of values that have 18 characters of morality there are several values contained in gurindam 12 including: 1) religious; 
2) honest; 3) nationalism; 4) love the motherland, 5) friendly/ communicative; 6) responsible. Where in gurindam 12 is full of advice about human relations with God, human relations, love for the motherland and how a human being should be able to become a good citizen in the nation.

In the words contained in the gurindam it is very thick Islamic nuances, because the gurindam does contain advice and advice that is very useful and is universal for the community, especially the community where Raja Ali Haji lived, namely the Malay community. This is possible because of the dominant element of Islam in social life in Malay culture as a result of the smooth process of Islamization in the region, particularly the Riau islands.

In line with the cultural theory above, in local wisdom Gurindam 12 in the City of Tanjung Pinang contains advice and advice that contains moral values that must be possessed by every human being in this life. The values contained in gurindam 12 must also be passed on to the children of the next generation so that the preservation of gurindam 12 in Malay will be maintained in the midst of globalization that continues to occur in Tanjung Pinang City which is a border area.

The process of inheritance gurindam 12 is not only carried out by families, at this time gurindam 12 is included in the curriculum of local content in schools in Tanjung Pinang City from elementary to high school level. This is done by the government to maintain the preservation of gurindam 12 and one of the steps that is considered quite maximal as a process of cultural inheritance to the younger generation who are the next generation. So that later their children and grandchildren can still know the great work of Raja Ali Haji who is a hero in the Riau Islands.

Local wisdom of Gurindam 12 in the life of Melay people in Tanjung Pinang City can be seen from how they normalize the environment by maintaining cleanliness of the sea and the coast, because of the geographical location of the city of Tanjung Pinang in the shape of the island, and can also be seen from the hospitality of the people who can coexist both with local residents and migrants.

\section{CONCLUSIONS}

From the discussion above it can be concluded that:First, through the role of education that continues to promote the values of local wisdom that aims to avoid social conflicts, disagreements, criminalization, and disputes that result in casualties and losses.Second, the best way to be able to encourage the values of local wisdom contained in the city of Tanjung Pinang is by including Gurindam 12 as a local content learning.Third, there are many things that can be taken as a form of appeal and advice for all community groups. Forth, Passing gurindam 12 to future generations so that one day our children and grandchildren can still know the great work of Raja Ali Haji who is a hero of the Riau Islands.

\section{REFERENCES}

[1] Gunawan, Agus Wibowo. (2015). Pendidikan karakter berbasis kearifan lokal di sekolah: konsep, strategi, dan implementasi. Yogyakarta: Pustaka Pelajar.

[2] Suryani, Ita (2014). Menggali Keindahan Alam Dan Kearifan Lokal Suku Baduy (Studi Kasus Pada Acara Feature Dokumenter "Indonesia Bagus" di Stasiun Televisi NET.TV). Musâwa, 13(2), pp. 180-193.

[3] Zamzami, Lucky (2016). Dinamika Pranata Sosial Terhadap Kearifan Lokal Masyarakat Nelayan Dalam Melestarikan Wisata Bahari. JURNAL ANTROPOLOGI: Isu-Isu Sosial Budaya, 18(1), pp. 57-67.

[4] Haryanto. (2014). Kearifan Lokal Pendukung Kerukunan Beragama pada Komunitas Tengger Malang diJawa Timur. Jurnal Analisa. 21(02). 
[5] Horton, B. Paul and Chester L. Hunt. (1996). Pengantar Sosiologi. Jakarta: Erlangga.

[6] Koentjaraningrat. (2002). Pengantar Ilmu Antropologi. Jakarta:PT Rineka Cipta.

[7] Mahsun. (2012). Metode Penelitian Bahasa: Tahapan Strategi, Metode, dan Tekniknya. Jakarta: RajawaliPers.

[8] Ratna, Nyoman Kutha. (2011). Paradigma Sosiologi Sastra. Yogyakarta: Pustaka Pelajar.

[9] Nazir, M. (1988). Metode Penelitian. Jakarta: Ghalia Indonesia.

[10] Padgett, Ron. (ed.) (2000). The Teachers and Writers Handbook of Poetic Forms. 2nd. New York: Teachers and Writers Collaborative.
[11] Sartini. (2004). Menggali Kearifan Lokal Nusantara: Sebuah Kajian Filsafati. Jurnal Filsafat, 37(2).

[12] Setiadi, Elly M. (2006). Ilmu Sosial Budaya Dasar. Jakarta: Kencana Prenada Media Group.

[13] Sibarani, Robert. (2012). Foklore sebagai Media dan Sumber Pendidikan: Sebua Ancangan Kurikulumdalam Pembentukan Karakter Siswa Berbasis Nilai Budaya Batak dalam Kearifan Lokal. Hakekat, Peran, dan Metode Tradisi Lisan (Endraswara Suwardied.). Jogyakarta: Penerbit Lontar.

[14] Yunus, Hadi Sabari. (2010). Metodologi Penelitian Wilayah Kontemporer. Yogyakarta: PustakaPelajar.

[15] Horton, Paul B dan Chester L. Hunt. (1996). Sosiologi. Jakarta: Penerbit Erlangga. 